\title{
Cytokine expression in mice exposed to diesel exhaust particles by inhalation. Role of tumor necrosis factor
}

\author{
Anne T Saber ${ }^{1}$, Nicklas R Jacobsen ${ }^{1}$, Jette Bornholdt ${ }^{1}$, Sanna L Kjær ${ }^{1}$, \\ Marianne Dybdahl ${ }^{1}$, Lotte Risom ${ }^{2}$, Steffen Loft ${ }^{2}$, Ulla Vogel ${ }^{1}$ and \\ Håkan Wallin*1
}

Address: ${ }^{1}$ National Institute of Occupational Health, Lersø Parkallé 105, 2100 Copenhagen, Denmark and ${ }^{2}$ Institute of Public Health, Copenhagen University, Øster Farimagsgade 5, opg. B, 2.sal; postbox 2099, 1014 Copenhagen K, Denmark

Email: Anne T Saber - ats@ami.dk; Nicklas R Jacobsen - nrj@ami.dk; Jette Bornholdt - jbo@ami.dk; Sanna L Kjær - slk@ami.dk; Marianne Dybdahl - mdy@ssi.dk; Lotte Risom - lotte.risom@farmakol.ku.dk; Steffen Loft - s.loft@pubhealth.ku.dk; Ulla Vogel - ubv@ami.dk; Håkan Wallin* - hwa@ami.dk

* Corresponding author

Published: 20 February 2006

Particle and Fibre Toxicology 2006, 3:4 doi:10.1186/1743-8977-3-4
Received: 24 October 2005

Accepted: 20 February 2006

This article is available from: http://www.particleandfibretoxicology.com/content/3/I/4

(C) 2006 Saber et al; licensee BioMed Central Ltd.

This is an Open Access article distributed under the terms of the Creative Commons Attribution License (http://creativecommons.org/licenses/by/2.0), which permits unrestricted use, distribution, and reproduction in any medium, provided the original work is properly cited.

\begin{abstract}
Background: Particulate air pollution has been associated with lung and cardiovascular disease, for which lung inflammation may be a driving mechanism. The pro-inflammatory cytokine, tumor necrosis factor (TNF) has been suggested to have a key-role in particle-induced inflammation.

We studied the time course of gene expression of inflammatory markers in the lungs of wild type mice and Tnf-/- mice after exposure to diesel exhaust particles (DEPs). Mice were exposed to either a single or multiple doses of DEP by inhalation. We measured the mRNA level of the cytokines $\operatorname{Inf}$ and interleukin-6 (II-6) and the chemokines, monocyte chemoattractant protein (Mcp-I), macrophage inflammatory protein-2 (Mip-2) and keratinocyte derived chemokine $(K c)$ in the lung tissue at different time points after exposure.
\end{abstract}

Results: $\operatorname{Tnf}$ mRNA expression levels increased late after DEP-inhalation, whereas the expression levels of II-6, Mcp-I and Kc increased early. The expression of Mip- 2 was independent of TNF if the dose was above a certain level. The expression levels of the cytokines $K c, M c p-I$ and $I I-6$, were increased in the absence of TNF.

Conclusion: Our data demonstrate that $T n f$ is not important in early DEP induced inflammation and rather exerts negative influence on $M c p-I$ and Kc mRNA levels. This suggests that other signalling pathways are important, a candidate being one involving Mcp-I.

\section{Background}

When deposited in the lung, ultra-fine particles, i.e. particles with a diameter less than $100 \mathrm{~nm}$, are probably more dangerous than large particles. The smaller the particles are, the greater surface area they have per mass unit: This implies that they have a greater chemical activity, can carry more PAH and other adsorbed chemicals, and they react more strongly with the lung tissue, thereby causing more inflammation than larger particles [1].

Several cytokines have been suggested to be involved in particle-induced inflammation. Focus has primarily been 
Table I: Expression of cytokines in lung tissue from BALBcJ mice exposed to SRMI650

\begin{tabular}{|c|c|c|c|c|c|c|c|c|}
\hline \multirow{2}{*}{$\begin{array}{l}\text { Dose } \\
\text { Time }\end{array}$} & \multicolumn{3}{|c|}{ Air } & \multicolumn{3}{|c|}{$20 \mathrm{mg} / \mathrm{m}^{3}$ DEP } & \multicolumn{2}{|c|}{$80 \mathrm{mg} / \mathrm{m}^{3}$ DEP } \\
\hline & I h & $3 \mathrm{~h}$ & I day & I h & $3 \mathrm{~h}$ & I day & I h & I day \\
\hline Tnf & $64 \pm 23$ & $41 \pm 7.5$ & $57 \pm 43$ & $49 \pm 23$ & $57 \pm 7.7$ & $100 \pm 39$ & $119 \pm 70$ & $178 \pm 66 * *$ \\
\hline $11-6$ & $0.4 \pm 0.3$ & $0.2 \pm 0.1$ & $0.2 \pm 0.1$ & $1.0 \pm 0.6 * *$ & $0.2 \pm 0.2$ & $0.2 \pm 0.01$ & $3.5 \pm 1.5^{* *}$ & $0.9 \pm 0.2^{* *}$ \\
\hline Mcp-I & $7.5 \pm 4.7$ & $21 \pm 21$ & $14 \pm 20$ & $8.5 \pm 4.8$ & $12.1 \pm 3.4$ & $11.6 \pm 2.0$ & $53.0 \pm 57^{*}$ & $129 \pm 86 * *$ \\
\hline Mip-2 & $20 \pm 10$ & $12 \pm 5.7$ & $22 \pm 17$ & $27.5 \pm 18$ & $12.6 \pm 1.2$ & $32.2 \pm 10.1$ & $63.4 \pm 17.4^{*}$ & $170 \pm 66^{* *}$ \\
\hline Kc & $4.0 \pm 1.5$ & $3.6 \pm 1.5$ & $2.7 \pm 1.4$ & $16.0 \pm 4.8^{* * *}$ & $4.5 \pm 1.8$ & $12.8 \pm 6.5^{* *}$ & $17.8 \pm 2.1 * *$ & $23.2 \pm 11.5^{* *}$ \\
\hline
\end{tabular}

Expression of mRNA is normalized to $18 \mathrm{~S}$ rRNA and is multiplied by $10^{7}$. Mean \pm S.D. is shown $(\mathrm{n}=3-7)$. IL-6 data has been published previously [8].

$* \mathrm{P}<0.05$ versus air-exposed mice.

$* * \mathrm{P}<0.01$ versus air-exposed mice.

directed to the cytokines tumor necrosis factor (TNF) and macrophage inflammatory protein (MIP-2, also called CXCL2), which have been suggested to play an important role in particle-induced inflammation in the lung [2]. TNF itself has no chemotactic effect for neutrophils. Thus, the chemotactic effect of TNF is thought to be mediated through the induction of chemotactic cytokines, the so called chemokines. The chemokines, MIP- 2 and keratinocyte derived chemokine (KC, also called CXCL1) are thought to be responsible for the recruitment of neutrophils in mice and exert their effect through binding to the same receptor CXCR2 [3]. MIP-2 and KC are considered to be murine homologues of the human interleukin8 [4]. Furthermore, the chemokine macrophage chemotactic protein 1 (MCP-1, also called CCL2) has recently been suggested to be involved in DEP-induced inflammation [5]. MCP-1 acts by binding to the MCP-1 receptor (also called CCR2), which promotes both the maturation of monocytes to macrophages as well as their chemotactic recruitment [6]. Finally, the expression of interleukin- 6 (Il-6) has been reported to be increased in particleinduced inflammation $[7,8]$.
We recently reported from an inhalation study, that TNF was not required for DEP-induced inflammation when we evaluated the inflammatory effects after four repeated inhalation exposures in Tnf -/- and Tnf +/+ mice [7]. The aim of the present study was to examine the short term effects of DEP exposure, i.e. the effects up to two days after exposure. This was done 1) by evaluating the importance of $T n f$ and other inflammatory markers after exposure and 2) by investigating whether Tnf deficiency induces a change in the time course of inflammation induced by DEP. We evaluated the inflammatory response at the mRNA level, because cytokine expression seems to be regulated at the transcriptional level and by mRNA stability. Furthermore mRNA can conveniently be quantified in tissues. It has been shown that DEP up-regulates several genes involved in the inflammatory response, at both the mRNA and protein level in rats [5].

\section{Results}

\section{Changes in cytokine expression over time}

To evaluate the time course of particle-induced inflammation, we measured the expression of five cytokines (Tnf, Il6, Mip-2, Kc and Mcp-1) in the lung tissue from BALBcJ (study 1 ) and C57xCBA mice (study 2) exposed to a single

Table 2: Expression of cytokines in the lung tissue from C57xCBA mice exposed to $80 \mathrm{mg} / \mathrm{m}^{3}$ SRM2975

\begin{tabular}{lccc}
\hline Exposure & Air & DEP & \\
\hline Marker & & $1-6 \mathbf{~}$ & I day \\
\hline Tnf & & $49 \pm 19$ & $14 \pm \pm 82^{* *}$ \\
II-6 & $0.47 \pm 0.25$ & $5.6 \pm 8.1^{* *}$ & $14 \pm 0.52^{* *}$ \\
Mcp-I & $5.3 \pm 1.9$ & $18 \pm 9.6^{* *}$ & $16 \pm 11^{*}$ \\
Mip-2 & $23 \pm 16$ & $43 \pm 37$ & $105 \pm 38^{* *}$ \\
Kc & $3.5 \pm 2.4$ & $9.4 \pm 6.7^{*}$ & $25 \pm 18^{* *}$ \\
\hline
\end{tabular}

Expression of mRNA is normalized to $18 \mathrm{~S} r R N A$ and is multiplied by $10^{7}$. Mean \pm S.D. is shown $(n=6-1 \mathrm{I})$.

$* \mathrm{P}<0.05$ versus air-exposed mice.

$* * P<0.01$ versus air-exposed mice. 
Table 3: Inflammatory response in Tnf+/+ and Tnf-/- mice exposed to a single dose of $20 \mathrm{mg} / \mathrm{m}^{3}$ SRM2975

\begin{tabular}{|c|c|c|c|c|c|}
\hline \multirow[t]{2}{*}{ Marker } & \multirow{2}{*}{$\begin{array}{c}\text { Exposure } \\
\text { Mice }\end{array}$} & \multirow[t]{2}{*}{ Air } & \multicolumn{3}{|c|}{ DEP } \\
\hline & & & I h & I day & 2 days \\
\hline $\operatorname{Tnf}$ & $\operatorname{Tnf}+/+$ & $47 \pm 15$ & $40 \pm 9.3$ & $89 \pm 36$ & $74 \pm 34$ \\
\hline \multirow[t]{2}{*}{$11-6$} & $\operatorname{Tnf}+/+$ & $\mathrm{I} . \mathrm{I} \pm 0.8$ & $3.0 \pm 1.9$ & $\mathrm{I} .3 \pm 0.8$ & $\mathrm{I} .7 \pm 0.7$ \\
\hline & $\operatorname{Tnf}-/-$ & $2.5 \pm 1.6$ & $4.8 \pm 2.8$ & $1.0 \pm 0.4$ & $2.6 \pm 2.6$ \\
\hline \multirow[t]{2}{*}{$M c p-I$} & $\operatorname{Tnf}+/+$ & $9.4 \pm 2.6$ & $21.9 \pm 9.2$ & $9.2 \pm 3.9$ & $15.4 \pm 3.9$ \\
\hline & $\operatorname{Tnf}-/-$ & $14.2 \pm 9.1$ & $39.5 \pm 29.4$ & $1 \mathrm{I} .4 \pm 4.4$ & $33.5 \pm 25$ \\
\hline \multirow[t]{2}{*}{ Mip-2 } & $\operatorname{Tnf}+/+$ & $8.1 \pm 0.8$ & $11.9 \pm 1.2$ & $19.5 \pm 8.2^{*}$ & $12.5 \pm 2.6$ \\
\hline & $\operatorname{Tnf}-/-$ & $6.6 \pm 2.5$ & $10.0 \pm 6.8$ & $8.6 \pm 2.2$ & $10.4 \pm 5.2$ \\
\hline \multirow[t]{2}{*}{ Kc } & $\operatorname{Tnf}+/+$ & $1.5 \pm 0.5$ & $1.9 \pm 0.6$ & $2.8 \pm 0.8$ & $2.3 \pm 1.3$ \\
\hline & $\operatorname{Tnf}-/-$ & $1.3 \pm 0.9$ & $3.5 \pm 2.2$ & $1.5 \pm 0.3$ & $2.6 \pm 0.7$ \\
\hline \multirow[t]{2}{*}{ Neutrophil (\%) } & $\operatorname{Tnf}+/+$ & $0.2 \pm 0.3$ & $0.7 \pm 0.3$ & $3.8 \pm 4 . I^{* *}$ & $7.3 \pm 5.8 * *$ \\
\hline & $\operatorname{Tnf}-/-$ & $0.4 \pm 0.8$ & $1.1 \pm 1.3$ & $0.9 \pm 0.8$ & $1.5 \pm 1.0$ \\
\hline
\end{tabular}

Tnf $+/+$ and Tnf-/- mice were exposed to a single dose of $20 \mathrm{mg} / \mathrm{m}^{3}$ SRM 2975 .

Expression of mRNA is normalized to $18 \mathrm{~S} r R N A$ and is multiplied by $10^{7}$. Mean \pm S.D. is shown $(n=4-5)$.

$* P<0.05$ versus air-exposed mice.

$* * \mathrm{P}<0.01$ versus air-exposed mice.

dose of DEP by inhalation at different time points. Study 1 consists of experiments with mice that we have reported of previously [8], and for which lung tissue in this study was reanalyzed for additional cytokines. Study 2 has not been reported of before. The results from the BALBcJ study and C57xCBA mice study are summarized in table 1 and table 2 , respectively.

The $\operatorname{Tnf}$ response occurred relatively late. No change in $\operatorname{Tnf}$ mRNA levels was seen 1 hour after exposure to $80 \mathrm{mg} / \mathrm{m}^{3}$ SRM1650 in BALBCJ mice compared to the mRNA level in mice exposed to filtered air, whereas the level was approximately 3 -fold elevated $(\mathrm{p}<0.01) 1$ day later (Table 1$)$. A marginal response was also only seen 1 day after the inhalation of $20 \mathrm{mg} / \mathrm{m}^{3}$. Similarly, in the experiment with the C57xCBA mice exposed to $80 \mathrm{mg} / \mathrm{m}^{3}$ SRM 2975 the expression level of Tnf was increased 1 day after exposure (3-fold, $\mathrm{p}<0.01$ ), whereas the expression level of Tnf was the same as in the air-exposed mice in the time-period from 1-6 hours after exposure (Table 2).

The expression level of the pro-inflammatory cytokine, Il6 was elevated over the entire period in both the BALBCJ and C57xCBA mice after exposure to $80 \mathrm{mg} / \mathrm{m}^{3}$ SRM1650 or SRM2975 ( $p<0.01$; Table 1 and 2). The highest level of expression was seen shortly after DEP inhalation (9-11fold within six hours, $\mathrm{p}<0.01$ ) compared to the airexposed, while the expression level was increased 4-fold $(\mathrm{p}<0.01) 1$ day after exposure to $80 \mathrm{mg} / \mathrm{m}^{3}$. Shortly after exposure $20 \mathrm{mg} / \mathrm{m}^{3}$ SRM1650 Il-6 was temporarily elevated by 2.5 -fold, showing a clear dose-response relationship (Table 1).
We measured the expression levels of the neutrophil chemotactic, chemokines, Mip-2 and $K c$ in BALBcJ mice exposed to a single dose of SRM1650 and C57xCBA mice exposed to a single dose of SRM2975. Mip-2 mRNA levels were increased in the BALBCJ mice exposed to $80 \mathrm{mg} / \mathrm{m}^{3}$ both 1 hour ( $\mathrm{p}<0.05,3$-fold) and 1 day ( $<<0.01,8$-fold) after exposure, whereas no change in expression levels was observed in the mice exposed to $20 \mathrm{mg} / \mathrm{m}^{3}$ at any time point (Table 1). In the C57xCBA mice, the expression level of Mip-2 was only increased 1 day after inhalation (5fold, $\mathrm{p}<0.05$ ) (Table 2). The expression level of $K c$ was statistically significantly increased in the BALBCJ mice exposed to $20 \mathrm{mg} / \mathrm{m}^{3} 1$ hour as well as 1 day after exposure, while there was no increase 3 hours after exposure (Table 1). In both BALBcJ and C57xCBA mice exposed to $80 \mathrm{mg} / \mathrm{m}^{3}$ the expression level of $K c$ was statistically significantly increased at both 1-6 hours and 1 day after exposure (Table 1 and 2). The expression level of the chemokine, $M c p-1$ was increased approximately 3 -fold in the C57xCBA mice 1 to 6 hours ( $\mathrm{p}<0.01)$ and 1 day (p < 0.05 ) after exposure (Table 2). The expression level of $M c p-1$ was increased in the BALBcJ mice exposed to 80 $\mathrm{mg} / \mathrm{m}^{3}$ both 1 hour (7-fold) and 1 day (9-fold) after exposure $(\mathrm{p}<0.01$ and $\mathrm{p}<0.05$, respectively), whereas no increase in expression level was seen at any time point in mice exposed to $20 \mathrm{mg} / \mathrm{m}^{3}$ (Table 1 ).

\section{TNF deficiency}

In a second set of experiments, we investigated the specific effect of TNF. This was done by comparing the inflammatory response in $T n f+/+$ and $T n f-/-$ mice after either a single dose of $20 \mathrm{mg} / \mathrm{m}^{3}$ SRM2975 (study 3) or multiple doses 
Table 4: Inflammatory response in Tnft/+ and Tnf-/- mice exposed to multiple doses of $20 \mathrm{mg} / \mathrm{m}^{3}$ SRM2975

\begin{tabular}{|c|c|c|c|c|c|}
\hline \multirow[t]{2}{*}{ Marker } & \multirow{2}{*}{$\begin{array}{c}\text { Exposure } \\
\text { Mice }\end{array}$} & \multicolumn{2}{|c|}{ Air } & \multicolumn{2}{|c|}{ DEP } \\
\hline & & Tnf $+/+$ & Tnf-I- & Tnf $+/+$ & Tnf-l- \\
\hline Tnf & & $6.0 \pm 4.4$ & & $13.8 \pm 3.7^{*}$ & \\
\hline $11-6$ & & $0.6 \pm 0.4$ & $1.2 \pm 0.6$ & $1.5 \pm 0.4^{*}$ & $4.2 \pm 1.7^{* *}$ \\
\hline Mcp-I & & $11.0 \pm 6.1$ & $7.5 \pm 3.8$ & $17.9 \pm 10.3$ & $33.8 \pm 16.6 * *$ \\
\hline Mip-2 & & $6.5 \pm 2.8$ & $5.3 \pm 2.5$ & $22.9 \pm 13.4^{* *}$ & $14.9 \pm 7.0^{* *}$ \\
\hline$K_{c}$ & & $2.1 \pm 1.0$ & $1.2 \pm 0.7$ & $2.5 \pm 0.8$ & $4.7 \pm 2.0^{* *}$ \\
\hline Neutrophil (\%) & & $3.4 \pm 6.7$ & $0.2 \pm 0.3$ & $12.3 \pm 7.9 * *$ & $16.5 \pm 10.1^{\text {*** }}$ \\
\hline
\end{tabular}

Expression of mRNA is normalized to I8S rRNA and is multiplied by $10^{7}$. Mean \pm S.D. is shown $(n=7-8)$. Neutrophil, TNF and IL6 data has been published previously [7].

$* \mathrm{P}<0.05$ versus air-exposed mice. $* * \mathrm{P}<0.01$ versus air-exposed mice.

of $20 \mathrm{mg} / \mathrm{m}^{3}$ SRM2975 (study 4). Study 3 is a new animal experiment, whereas we have reported of the animal experiments in study 4 before [7], however, for which lung tissue was reanalyzed for new cytokines in this study.

\section{Single dose study in Tnf deficient mice}

We studied the time course of inflammation by measuring the expression levels of the cytokines Tnf, Il-6, Mip-2, Kc and Mcp-1 in the lungs of the Tnf+/+ and Tnf-/- mice at 1 hour, 1 and 2 days after end of exposure to a single dose of $20 \mathrm{mg} / \mathrm{m}^{3}$ SRM2975. In addition, we assessed the recruitment of inflammatory cells into the lung lumen. We chose to evaluate the time course after a single dose of $20 \mathrm{mg} / \mathrm{m}^{3}$ SRM2975 in Tnf+/+ and Tnf-/- mice on the background of our previous results, that showed that Il- 6 expression was significantly increased in BALB/CJ mice exposed to a single dose of $20 \mathrm{mg} / \mathrm{m}^{3}$ SRM 1650 [8]. The results from the single dose study using Tnf proficient and deficient mice are summarized in table 3 .

In the $T n f+/+$ mice the fraction of neutrophils in the BAL cells was strongly increased 1 (about 15-fold, $\mathrm{p}<0.01$ ) and 2 days after exposure (about 30 -fold, $\mathrm{p}<0.01$ ) (Table 3 ). In the DEP exposed Tnf-/- mice there were 2-3-fold more neutrophils compared to the air exposed. This was not significantly different, but there was also no stastistical difference between knock out mice and wild type at any time point. We measured the expression levels of the cytokines Tnf, Il-6, Mip-2, Kc and Mcp-1 in the lung tissue. DEP exposure caused a 2-fold increase in $T n f$ mRNA levels in the Tnf+/+ mice 1 day after exposure compared to the air-exposed mice, although not statistically significant. As expected, no expression of Tnf was detected in the Tnf-/mice. DEP exposure caused no significant change in expression levels of $I l-6, M c p-1$ and $K c$ in neither the Tnf+/ + nor the Tnf-/- mice, at any time point. Although the difference was not statistically significant, the levels of $M c p-1$ were higher in the Tnf-/- mice than the Tnf-/+ at the same time points. The level of Mip-2 expression in the DEP exposed $T n f_{+} /+$mice was increased 1 day $(\mathrm{p}<0.05)$ after exposure compared to the air exposed mice. The Tnf-/mice did not respond to the DEP exposure with a higher Mip-2 expression.

\section{Repeated dose study in Tnf deficient mice}

We studied the inflammatory response in Tnf deficient and proficient mice to repeated DEP doses by measuring the expression levels of Mip-2, Kc and Mcp-1 in the lung tissue from mice exposed to four bouts of inhalation of 20 $\mathrm{mg} / \mathrm{m}^{3}$ SRM2975 (Table 4). In both the Tnf+/+ and the Tnf-/- mice, DEP exposure increased the expression levels of Mip-2 around 3-fold ( $\mathrm{p}<0.5, \mathrm{p}<0.01)$. The expression level of $K c$ was significantly increased in the Tnf -/- mice (p $<0.01$ ), but there was no increase of expression level in the $T n f_{+} /+$mice. The Mcp-1 expression levels were increased 5-fold in the Tnf deficient mice $(\mathrm{p}<0.01)$, and 1.5 -fold in the $T n f+/+$ mice although the latter was not statistically significant. In our recent publication [7], we analyzed the expression levels of Tnf and Il-6 mRNAs in the lung tissue and determined the fraction of neutrophils in the BAL cells. Results from this and the present study are summarized in table 4.

\section{Discussion}

It has been suggested that TNF is a key-player in particleinduced inflammation [2], and that TNF is an inflammatory mediator upstream of MIP-2 and KC [9]. However, in a previous study, we exposed $T n f+/+$ mice and $T n f-/-$ mice to DEP by inhalation, and showed that TNF is not required for DEP-induced inflammation [7]. In the present study we provide further evidence that TNF is not important in early DEP-induced inflammation. Exposure to higher doses of DEP increased the expression level of Mip-2, independently of Tnf status, whereas enhanced $K c$ expression preceded Mip-2 expression only in Tnf-/- mice, which suggests that $K c$ may compensate for the deficiency of Tnf, or that TNF exerts negative feedback on KC signalling. The DEP-induced expression of $M c p-1$ and Il-6 occurred in the absence of Tnf. Our results indicate that other signalling pathways, perhaps involving MCP-1, are 
important for early DEP induced neutrophilic inflammation.

Thus, we evaluated other signalling patways with the expression of four additional cytokines, Il-6, Mip-2, Kc and $M c p-1$, in the early and late phase of the DEP-induced inflammatory process. The results from the BALBcJ [8] and the C57xCBA mice studies, show very clearly that Il-6 is expressed early in inflammation (1-6 hours after exposure) and that the expression of Il-6 has declined a day after exposure, although it is also elevated after repeated exposures.

The chemokines Mip-2 and $K c$ are strongly coupled to the influx of neutrophils in the rodent lung [4], whereas MCP1 is chemotactic for monocytes. MIP- 2 and MCP-1 have both been linked to the inflammatory process in response to particles $[2,5]$. All of these three cytokines were more expressed 1 hour after exposure to a high dose $(80 \mathrm{mg} /$ $\mathrm{m}^{3}$ ) independently of mouse strain or type of DEP. Mip-2 levels increased further 1 day after exposure and this also included the low dose of SRM2975, whereas a further increase in Mcp-1 mRNA levels only occurred after SRM1650 in BALBCJ mice and not with SRM2975. The mRNA levels of $K c$ were maximal at 1 hour after exposure to SRM1650 and even showed a decrease 3 hours after exposure to $20 \mathrm{mg} / \mathrm{m}^{3}$, although there was a slight further increase 1 day after exposure to $80 \mathrm{mg} / \mathrm{m}^{3}$ SRM2974. Only the $K c$ level was significantly increased 1 hour after the low dose of $20 \mathrm{mg} / \mathrm{m}^{3}$ SRM 1650 in BALBcJ mice. Accordingly, Il-6, Mip-2, Mcp-1 and $K c$ are cytokines induced in the early phase of DEP-induced inflammation, while Tnf is expressed late at about a day after exposure. Mip-2 may have a more important role in the later phase as judged by the further increased expression 1 day after exposure. The results may be consistent with that DEP activates Toll like receptor 4 (TLR4) signalling because the Tnf response occurs late in this pathway. In fact, there are indications that air pollution particles stimulate the TLR4 pathway [10-12]. Bacterial lipopolysaccharide (LPS), the best studied stimulator of the TLR4 pathway, binds to the TLR4 and activates nuclear factor $\kappa \mathrm{B}(\mathrm{NF}-\kappa \mathrm{B})$ mediated neutrophil inflammation. The TLR4 signals in two parallel pathways, both leading to activation of NF- $\kappa B$. The MyD88 adaptor dependent pathway directly activates NF- $\kappa \mathrm{B}$, whereas in a later pathway, dependent on interferon- $\beta$ adaptor molecule and probably on interferon-regulatory factor $3, \mathrm{NF}-$ $\kappa \mathrm{B}$ activation is dependent on de novo synthesis, secretion, and autocrine signalling by TNF over the TNF receptors $[13,14]$. Moreover, a few studies support our results that TNF is of no or minor importance in particle-induced inflammation in the lungs of rodents. E.g., recently, a highly increased expression levels of the chemokines, Mcp-1 and Mip-2, but no change in Tnf, was found in BAL cells isolated from DEP (SRM2975) exposed rats [5]. This is in accordance with, that BALF from rats exposed to quartz by intratracheal instillation contained increased MIP-2 protein levels over the measured time period from 3 to 90 days after exposure, whereas TNF protein levels remained under the detection limit [15]. However, when comparing our study with the above mentioned studies, it should be noticed that they describe the long term effects of particles, i.e. the effects in a time window from 1-30 and 3-90 days after exposure, respectively, while this study describes short term effects of particles, i.e. $1 \mathrm{hr}$ to 2 days after exposure.

As we have previously reported, Il-6 was upregulated upon repeated DEP exposure both in $T n f+/+$ and $T n f-/-$ mice [7]. This might be consistent with a report showing that SRM2975 increased IL-6 in BALF, whereas no change in TNF protein levels were observed [16]. Although not statistically significant, the Il-6 expression level was higher 1 hour after exposure in both $T n f+/+$ mice and Tnf-/- mice after a single dose exposure.

In the repeated dose TNF study, both the Tnf+/+ and Tnf-/ - mice responded with an increase in Mip-2 response in the lungs. The Mip-2 induction was similar in $T n f+/+$ and Tnf-/- mice. This is surprising because MIP-2 was believed to be an inflammatory marker downstream of TNF [9]. MIP-2 has been strongly linked to the influx of neutrophils [2]. In the single dose TNF study, the level of expression of Mip-2 was increased in the $T n f+/+$ mice 1 day after exposure and borderline significant 2 days after exposure. The Mip-2 expression tended to correlate with the influx of neutrophils, because the influx of neutrophils was statistically significant 1 day and 2 days after exposure. Similarly, TNF receptor 1 deficient mice had an intact neutrophil infiltration after pulmonary exposure to silica [17]. No increase in Mip-2 mRNA levels was seen in the single dose exposed Tnf -/- mice at any time: Possibly, there is a threshold for the induction of Mip-2 in the Tnf /- mice, because the repeated exposure in the $\operatorname{Tnf} f$ deficient mice resulted in a Mip-2 response. In the repeated dose experiment, the expression of $K c$ was only increased in the Tnf-/- mice, which together with the results from the BALBcJ and C57xCBA mice suggests that TNF exerts an inhibitory effect on $K c$ expression.

MIP-2 and KC are both chemotactic for neutrophils and have been suggested to be redundant [18]. MIP-2 has a higher affinity to the CXCR2 receptor than cytokineinduced neutrophil chemoattractant (CINC), the rat analogue to $\mathrm{KC}$, and is a more potent chemotactic factor for neutrophils [19]. The expression of $K c$ increased earlier than Mip-2. This is consistent with a recent report that CINC (KC) apparently functions as a priming signal to the neutrophils, which afterwards are attracted to the more potent but local chemoattractant MIP-2 in the lung [20]. 
Our results show that both Mip-2 and $K c$ are increased in the absence of Tnf. Both $M c p-1$ and $K c$ mRNA levels were induced to lesser extent by DEP in the Tnf+/+ than in the Tnf-/- mice. This might indicate TNF exerts negative feedback on these cytokines.

Recently, it was reported that primary embryonic fibroblasts from Tnf-/- mice had intact LPS induction of Mcp-1 expression levels [13]. Knock out mice with abrogated MCP-1 signalling have indeed impaired macrophage and neutrophil infiltration upon some toxic stimuli to the lung [9-11]. This calls for further research into the importance of TLR4, MCP-1 and other early response signalling in particle-induced inflammation.

In one of our experiments we used the SRM1650 material which is particulate matter collected from a heavy-duty diesel engine. Because this is not available any more, we used SRM2975 in the rest. SRM2975 is a DEP preparation collected from a diesel-powered industrial forklift. The DEP materials differ in their chemical composition. E.g., SRM 1650 contain a higher amount of metals and PAHs than SRM 2975 [21,22]. Although we have not compared this in depth, similar responses were obtained using the two different DEP preparations although the SRM1650 seemed to give a stronger response particularly with respect to MCP-1.

These experiments were performed using several different mouse strains. There were minor differences in expression patterns, which may be ascribed to strain or DEP material effects. The overall picture was consistent across mouse strains, indicating that the observed effects are not strain specific.

\section{Conclusion}

In summary, we have shown that TNF is not important in early DEP-induced inflammation. Exposure to DEP by inhalation caused an increased expression level of Mip-2, that was independent of Tnf status, if the dose was above a certain level. $K c$ expression seemed to precede the Mip-2 expression and $K c$ was only expressed at a higher level in the DEP-exposed Tnf-/- mice, which suggests that KC may compensate for the deficiency of TNF, or that TNF exerts negative feedback on KC signalling. The DEP-induced expression of Mcp-1 and Il-6 was increased in the absence of Tnf. Our results indicate that TNF signalling is not important for early DEP induced neutrophilic inflammation. Attention should be focused on other pathways, a possible candidate being one involving MCP-1.

\section{Methods \\ Animals}

Tnf-/- mice (B6, 129S-Tnftm1Gk1) were obtained from JAX Mice (USA). C57 BL/6J mice were used as Tnf+/+ mice. $\mathrm{C} 57 \mathrm{BL} / 6 \mathrm{~J}$ and BALBcJ mice were purchased from Taconic Europe, Denmark. C57xCBA mice that express luciferase under the control of NFKB [23] were obtained from Rune Blomhoff, Norway (hereafter referred to as C57xCBA mice). The mice were allowed to acclimatize for 2 weeks and were given food (Altromin 1324) and water ad libitum. The mice were group housed in polypropylene cages with sawdust bedding at controlled temperature 21 $\pm 1^{\circ} \mathrm{C}$ and humidity $50 \pm 10 \%$ with a 12 -h light: 12 -h dark cycle. Female Tnf-/- and $T n f+/+$ mice were studied at 9-11 weeks of age. Both male and female C57xCBA mice were studied at 7-8 weeks of age. Female BALBCJ mice were studied at 8 weeks of age.

\section{Particles}

DEP were Standard Reference Material 2975 and 1650 from the National Institute of Standards and Technology (NIST)(Gaithersburg, MD, USA). SRM1650 are combustion particles from a heavy duty diesel engine. SRM2975 are DEP collected from a diesel-powered industrial forklift. A detailed description of the particles can be viewed at [22].

\section{Exposure of mice}

The study consists of four parts: 1) a single exposure of BALBCJ mice to 20 or $80 \mathrm{mg} / \mathrm{m}^{3}$ SRM1650, 2) a single dose exposure of C57xCBA mice to $80 \mathrm{mg} / \mathrm{m}^{3}$ SRM2975, 3) a single dose exposure of $T n f-/-$ mice and $T n f+/+$ mice to 20 $\mathrm{mg} / \mathrm{m}^{3}$ SRM2975, and 4) four repeated exposures of Tnf-/ - mice and $T n f+/+$ mice to $20 \mathrm{mg} / \mathrm{m}^{3}$ SRM2975. In all four parts, the mice were exposed by inhalation for 90 minutes either one single time (study 1,2 and 3) or repeated on each of four consecutive days (study 4) in an 18 l noseonly exposure chamber.

1) The design of the single dose exposure of BALBcJ mice has been described elsewhere [8]. In summary, the mice were exposed to either $20 \mathrm{mg} / \mathrm{m}^{3}$ or $80 \mathrm{mg} / \mathrm{m}^{3}$ SRM 1650 and the endpoints were analyzed 1 hour, 3 hours or 1 day (22 hours) after exposure.

2) C57xCBA mice were exposed to a single dose of $80 \mathrm{mg} /$ $\mathrm{m}^{3}$ SRM2975. Endpoints were analyzed at different time points.

3 ) In the third study, the mice were exposed a single time to $20 \mathrm{mg} / \mathrm{m}^{3}$ SRM 2975 at similar conditions as the repeated exposure. Endpoints were analyzed 1 hour, 1 and 2 days after end of last exposure. Study 2 and our previous studies show that the levels of expression of inflammatory cytokines are unchanged over time in the airexposed mice [8]. On that background and because of ethical considerations, we chose only to evaluate the airexposed mice at a single time point. 
4) The design of the repeated exposure has been described in detail elsewhere [7]. In brief, we exposed Tnf-/- mice and $T n f+/+$ mice by inhalation to $20 \mathrm{mg} / \mathrm{m}^{3}$ DEP or filtered air for $90 \mathrm{~min}$ on each of four consecutive days. One hour after the last inhalation the mice were killed and organs were snap frozen in liquid nitrogen and stored at $80^{\circ} \mathrm{C}$. Endpoints were analyzed.

The particles were aerosolized by a microfeeder with dispersion nozzle (Fraunhofer Institut für Toxikologie and Aerosolforschung, Hannover, Germany). The number of particles was measured by a condensation particle counter (TSI model 3022A). The numbers of particles in the single dose TNF study and C57xCBA study were about $9.1 \cdot 10^{5} /$ $\mathrm{cm}^{3}$ and $3.0 \cdot 10^{6} / \mathrm{cm}^{3}$, respectively. Particle numbers in the multiple-dose TNF study and the BALBcJ study are described elsewhere $[7,8]$. The particle concentration was measured four times during exposure by weighing of filters. The particle concentrations in the single dose TNF study and C57xCBA study were approximately $20 \mathrm{mg} / \mathrm{m}^{3}$ and $80 \mathrm{mg} / \mathrm{m}^{3}$, respectively.

After exposure, tissue and BAL cells from the mice were for all studies prepared as described previously $[7,8]$.

\section{Preparation of RNA and cDNA from lung tissue}

RNA from the multiple dose experiment was prepared using NucleoSpin 96 RNA kit (Macherey-Nagel) as described previously [7]. RNA from the three single dose experiments were prepared using QIAamp ${ }^{\circledR}$ RNA Blood Mini Kit (Qiagen, USA) as described by the manufacturer. cDNA was prepared from DNase treated RNA using TaqMan reverse transcription reagents (Applied Biosystems, USA) as described by manufacturer.

\section{Real time RT-PCR}

The Tnf, Mip-2, Kc, Il-6 and Mcp-1 gene expression was determined using real-time RT-PCR with $18 \mathrm{~S}$ RNA as the reference gene. Each sample was run in triplicate on the ABI PRISM 7700 sequence detector (PE Biosystems, Foster City, CA, USA). For TNF, IL6 and MCP-1, TaqMan predeveloped reaction kits (Applied Biosystems, USA) were used. Unfortunately, the TaqMan pre-developed reaction kit for determination of TNF, we previously used [7], is not commercially available anymore. Therefore we had to change to another TNF kit: nr 4331182 (Applied Biosystems, USA). This means that is not possible to compare the results of TNF in this publication with the results published in our former publication [7]. The expression levels of Tnf are approximately 5-fold higher when using the new kit. For MIP-2 and $\mathrm{KC}$, probes and primers were designed as described previously [24]. However, the $\mathrm{KC}$ sense primer was modified at two nucleotide positions to: 5'-gtg tct agt tgg tag ggc ata at-3', because the assay did not work with the published primer [24]. This was probably due to interspecies variations. In all assays TaqMan predeveloped mastermix (Applied Biosystems) was used. For the $\mathrm{KC}$-assay the $\mathrm{MgCl}_{2}$ concentration was adjusted to 3.0 $\mathrm{mM}$. Target and 18S RNA levels were quantified in separate tubes. The target genes were normalized $\left(\Delta \mathrm{C}_{t}\right)$ to $18 \mathrm{~S}$ RNA by subtracting the cycle threshold value of $18 \mathrm{~S}$ RNA $\left(\mathrm{C}_{\text {treference }}\right)$ from the $\mathrm{Ct}$ value of the gene of interest $\left(\mathrm{C}_{\mathrm{tta}}\right.$ rget), i.e. $\Delta \mathrm{C}_{\mathrm{t}}=\mathrm{C}_{\mathrm{ttarget}}-\mathrm{C}_{\text {treference. }}$. The relative expression of the target gene was calculated by the comparative method $2^{-\Delta \mathrm{Ct}}[25]$. The average standard deviation on triplicates was $15 \%$. The standard deviation on repeated measurements of the same sample (the control) in separate experiments was $20 \%$, indicating that the day-to day variation of the assay was $20 \%$. The probes and primers have been validated and the PCR was shown to be quantitative over a range of 32 or 64-fold range. Messenger RNA measurements were excluded if the $18 \mathrm{~S}$ content fell outside the range in which the PCR was found to be quantitative defined by the validation experiments. Negative controls, where RNA was not converted to cDNA, were included in each run.

\section{Statistical analysis}

Data from the study 1, 3 and 4 were analyzed by two-way analysis of variance. Data from study 2 were analyzed by one-way analysis of variance. To fulfil the criteria for normality and variance homogeneity some of the markers were logarithmically transformed once or twice. For some markers, the data were ranked before a nonparametric test, because it was not possible to transform the data in a way that satisfied the criteria for normality and variance homogeneity. To determine the statistical significance of biomarkers, pairs of interest were compared with Tukey's Studentized range test with control of type 1 experimental error. In study 3, one mouse was excluded as an outlier because the data points for this mouse were more than 2 standard deviations from the rest of the data for all endpoints except one. In study 2 the air-exposed mice were grouped. Statistical analysis was performed with the SAS 8.2 statistical program.

\section{Competing interests}

The author(s) declare that they have no competing interests.

\section{Authors' contributions}

ATS carried out the real-time RT analysis, performed the statistical analysis and drafted the manuscript. NRJ, JBO, SLK, LR and MD carried out the exposure of the mice. ATS, SL, UBV and HWA conceived of the study and participated in its design and coordination. HWA, UBV and SL helped to draft the manuscript. All authors read and approved the final manuscript.

\section{Acknowledgements}


This work was supported by Danish Medical Research Council (no 205203-0016), the Airpolife center of excellence granted by the Danish Research agency and a scholarship to Anne Thoustrup Saber by the Danish Research Academy. The technical assistance from Birgitte Korsholm is gratefully acknowledged. The experiments were approved by the Danish "Animal Experimental Inspectorate" and carried out following their guidelines for ethical conduct and care when using animals in research.

\section{References}

I. Oberdörster G: Pulmonary effects of inhaled ultrafine particles. Int Arch Occup Environ Health 200I, 74:I-8.

2. Driscoll KE: TNFalpha and MIP-2: role in particle-induced inflammation and regulation by oxidative stress. Toxicol Lett 2000, I I 2-I I 3: I77-183.

3. Cacalano G, Lee J, Kikly K, Ryan AM, Pitts-Meek S, Hultgren B, Wood WI, Moore MW: Neutrophil and B cell expansion in mice that lack the murine IL-8 receptor homolog. Science 1994, 265:682-684.

4. Haelens A, Wuyts A, Proost P, Struyf S, Opdenakker G, van Damme J: Leukocyte migration and activation by murine chemokines. Immunobiology 1996, 195:499-52 I.

5. Rao KM, Ma JY, Meighan T, Barger MW, Pack D, Vallyathan V: Time course of gene expression of inflammatory mediators in rat lung after diesel exhaust particle exposure. Environ Health Perspect 2005, I | 3:6 |2-617.

6. Tangirala RK, Murao K, Quehenberger O: Regulation of expression of the human monocyte chemotactic protein-I receptor (hCCR2) by cytokines. J Biol Chem 1997, 272:8050-8056.

7. Saber AT, Bornholdt J, DybdahI M, Sharma AK, Loft S, Vogel U, Wallin $\mathrm{H}$ : Tumor necrosis factor is not required for particle-induced genotoxicity and pulmonary inflammation. Arch Toxicol 2005, 79:177-182.

8. Dybdahl M, Risom L, Bornholdt J, Autrup H, Loft S, Wallin H: Inflammatory and genotoxic effects of diesel particles in vitro and in vivo. Mutat Res 2004, 562:| | 9-131.

9. Tessier PA, Naccache PH, Clark-Lewis I, Gladue RP, Neote KS, McColl SR: Chemokine networks in vivo: involvement of C-X$C$ and $C-C$ chemokines in neutrophil extravasation in vivo in response to TNF-alpha. J Immunol 1997, 159:3595-3602.

10. Becker S, Fenton MJ, Soukup JM: Involvement of microbial components and toll-like receptors 2 and 4 in cytokine responses to air pollution particles. Am J Respir Cell Mol Biol 2002, 27:6II-6I8.

II. Gilmour PS, Schladweiler MC, Richards JH, Ledbetter AD, Kodavanti UP: Hypertensive rats are susceptible to TLR4-mediated signaling following exposure to combustion source particulate matter. Inhal Toxicol 2004, 16 Suppl 1:5-18.:5-18.

12. Cho HY, Jedlicka AE, Clarke R, Kleeberger SR: Role of Toll-like receptor-4 in genetic susceptibility to lung injury induced by residual oil fly ash. Physiol Genomics 2005, 22: 108-1 17 .

13. Werner SL, Barken D, Hoffmann A: Stimulus specificity of gene expression programs determined by temporal control of IKK activity. Science 2005, 309:|857-|86|.

14. Covert MW, Leung TH, Gaston JE, Baltimore D: Achieving stability of lipopolysaccharide-induced NF-kappaB activation. Science 2005, 309: 1854-1857.

15. Albrecht C, Schins RP, Hohr D, Becker A, Shi T, Knaapen AM, Borm $P J:$ Inflammatory time course after quartz instillation: role of tumor necrosis factor-alpha and particle surface. Am J Respir Cell Mol Biol 2004, 3 I:292-30I.

16. Singh P, DeMarini DM, Dick CA, Tabor DG, Ryan JV, Linak WP, Kobayashi T, Gilmour MI: Sample characterization of automobile and forklift diesel exhaust particles and comparative pulmonary toxicity in mice. Environ Health Perspect 2004, I I 2:820-825.

17. Pryhuber GS, Huyck HL, Baggs R, Oberdorster G, Finkelstein JN: Induction of chemokines by low-dose intratracheal silica is reduced in TNFR I (p55) null mice. Toxicol Sci 2003, 72: I 50 - I57.

18. Zhang XW, Wang Y, Liu Q, Thorlacius $\mathrm{H}$ : Redundant function of macrophage inflammatory protein-2 and $K C$ in tumor necrosis factor-alpha-induced extravasation of neutrophils in vivo. Eur J Pharmacol 200I, 427:277-283.

19. Murakami K, Shibata F, al Mokdad M, Nakagawa H, Ueno A, Kondo $\mathrm{T}$ : Identification and characterization of receptor for cytokine-induced neutrophil chemoattractant-3 on rat neutrophils. Biochem Biophys Res Commun 1997, 232:562-567.

20. Quinton LJ, Nelson S, Zhang P, Boe DM, Happel KI, Pan W, Bagby G]: Selective transport of cytokine-induced neutrophil chemoattractant from the lung to the blood facilitates pulmonary neutrophil recruitment. Am J Physiol Lung Cell Mol Physiol 2004, 286:L465-L472.

21. Aust AE, Ball JC, Hu AA, Lighty JSSKRSAM, Veranth JM, Young WC: Research report. Particle Characteristics Responsible for Effects on Human Lung Epithelial Cells. Health Effects Institute 2002.

22. National Institute of Standards and Technology: - [http:// www.nist.gov].

23. Carlsen H, Moskaug JO, Fromm SH, Blomhoff R: In vivo imaging of NF-kappa B activity. J Immunol 2002, 168: |44|-| 446.

24. Chiu BC, Shang X, Frait KA, Hu JS, Komuniecki E, Miller RA, Chensue SW: Differential effects of ageing on cytokine and chemokine responses during type-I (mycobacterial) and type-2 (schistosomal) pulmonary granulomatous inflammation in mice. Mech Ageing Dev 2002, I 23:313-326.

25. Livak KJ, Schmittgen TD: Analysis of relative gene expression data using real-time quantitative PCR and the 2(-Delta Delta C(T)) Method. Methods 200I, 25:402-408.
Publish with BioMed Central and every scientist can read your work free of charge

"BioMed Central will be the most significant development for disseminating the results of biomedical research in our lifetime. "

Sir Paul Nurse, Cancer Research UK

Your research papers will be:

- available free of charge to the entire biomedical community

- peer reviewed and published immediately upon acceptance

- cited in PubMed and archived on PubMed Central

- yours - you keep the copyright

Submit your manuscript here:

http://www.biomedcentral.com/info/publishing_adv.asp
BioMedcentral 